\title{
EVALUATION OF CEMENTING EFFICIENCY OF QUATERNARY BLENDED HIGH STRENGTH SELF COMPACTING CONCRETE
}

\author{
S Shrihari ${ }^{1}$, M V Seshagiri Rao ${ }^{2}$, V Srinivasa Reddy ${ }^{3}$ \\ ${ }^{1}$ Associate Professor of Civil Engineering J.B Institute of Engineering \&Technology, Hyderabad, \\ shriharistructure@gmail.com \\ ${ }^{2}$ Professor and Dean, Department of Civil Engineering, CVR College of Engineering, Hyderabad, \\ rao_vs_meduri@yahoo.com \\ ${ }^{3}$ Professor, Department of Civil Engineering, GRIET, Hyderabad,vempada@gmail.com
}

\begin{abstract}
The utilization of Supplementary Cementitious Materials (SCM) is well accepted because of the several improvements possible in the concrete composites, and due to the overall economy. Research work till date suggests that use of SCMs improve many of the performance characteristics of the hardened concrete. From the present investigations it is found that the compressive strength of metakaolin based high strength Self Compacting Concrete( SCC) depends both on the age and the percentages of replacement levels of Metakaolin, Micro Silica and Fly ash combination. The proposed work attempts to quantify the strength of Metakaolin, Silica fume and Fly ash combinationat the various optimum replacement levels and evaluate their efficiencies in SCC. In recent years replacement of cement with optimum combination of SCMs has emerged as a major alternative to conventional SCC and has rapidly drawn the concrete industry attention due to its cement savings, energy savings, and cost savings, environmental and socio-economic benefits. The present work proposes to report the results of an experimental study conducted to evaluate the synergic effects of Metakaolin, Micro Silica and Fly ash combinationcompressive strength of hardened Quaternary blended high strength SCC of M80 grades at different ages. The strength efficiency factor ' $k$ ' are evaluated usingBolomey's empirical expressions which are frequently used to predict the strength of concrete theoretically. The overall strength efficiency was found to be a combination of general efficiency factor, depending on the age and a percentage efficiency factor, depending upon the percentage of replacement of MetaKaolin, Silica fume and Fly ash combination. The experimental work on Micro Silica (MS) and MetaKaolin $(M K)$ concrete found that the computed efficiency factor varied with pozzolan type, replacement level and age at 90 days. The value of $k$ range from 1.71 to 1.84 for micro silica and MetaKaolin for 7 days . 1.16 to 1.11 for 28 days and 1.11 to 1.07 for 90 days in ternary blended SCC.The value of K quaternary blended SCC range from 1.88 for 7 days , 1.6 for 28 days and 1.19 for 90 days with $34 \%$ of waste industrial by product
\end{abstract}

Keywords: Self Compacting Concrete, Metakaolin, Micro Silica, Fly Ash, Efficiency Factor, Ternary Blended SCC, Quaternary Blended SCC

\section{INTRODUCTION}

The Extensive research work for decades is in progress throughout the globe in concrete technology in finding alternative materials which can partially or fully replace ordinary Portland cement (OPC) and which can also meet the requirements of strength and durability aspects. Amongst the many alternative materials tried as partial cement replacement materials, the strength, workability and durability performance of industrial by products like fly ash (FA), blast furnace slag, microsilica, metakaolin, rice husk ash, etc., now termed as Supplementary cementitious materials (SCMs) are quite promising. Subsequently, these have led to the development of binary, ternary and quaternary blended concretes depending on the number of SCMs and their combinations used as partial cement replacement materials. The use of appropriately proportioned ternary or quaternary blended concretes allows the effect of one SCM to compensate for the inherent shortening of another. The one of the main objectives of this research was to investigate synergistic action of ternary selfcompacting concretes (SCC) on rheological properties, strength and their cementing efficiencies in SCC. Several research studies have reported on the performance of Rice husk Ash (RHA) and Microsilica (MS) blended SCC. However, very limited research information was reported on the synergic action of Metakaolin and Microsilica in SCC for high performance concretes. The present investigations are aimed to study (1) the effect of synergic action of Metakaolin (MK), Microsilica (MS) and fly ash (FA) in SCC on Rheological behavior such as flowing, passing and filling ability; Strength properties and (2) their cementing efficiencies of FA, MS and MK in binary, ternary and quaternary blended SCCs.

\section{RESEARCH SIGNIFICANCE}

Research work till date suggests that Metakaoline (MK), Microsilica (MS) improve many of the performance characteristics of the SCC such as strength, workability, permeability, and durability. From the present investigations it is found that the compressive strength of MK and MS based SCC depends both on the age and the percentage replacement level. It is felt that efficiency concept can be 
used to understand the behavior of MK and MS in SCC.In the present studies, Nan Su mix design method is adopted to determine the quantities of materials in $\mathrm{kg}$ per cu.m for high strength grade (M80) of blended Self Compacting Concrete (SCC). This paper presents a study on the behavior of MK and MS in SCC performance by evaluating the efficiency of MK and MS at different percentages of replacement for high strength grade (M80) grades in terms of efficiency factor " $k$ ". The strength efficiency factors for MK,MS and $\mathrm{MK}+\mathrm{FA}, \mathrm{MS}+\mathrm{FA}$ dosages (in terms of percentage replacement) in SCC Mixes arecomputed based on the compressive strength of OPC only SCC mixes.

\section{BOLOMEY'S EMPIRICAL EXPRESSION}

The Bolomey's empirical expression frequently used to predict the strength of concrete is theoretically well founded when applied to hardened concrete.

Efficiency factors found from this strength equation are used to describe the effect of the MK and MS replacement. Efficiency factors are generally used to describe the impact of MK, MS and FA replacement on the compressive strength of SCC Mixes.

The Bolomey's equation is:

$\mathrm{S}=\mathrm{A}[(\mathrm{c} / \mathrm{w})]+\mathrm{B}$

' $\mathrm{S}$ ' is the compressive strength in $\mathrm{MPa}$, ' $\mathrm{c}$ ' is the cement content in $\mathrm{kg} / \mathrm{m}^{3}$, ' $\mathrm{w}$ ' is the water content in $\mathrm{kg} / \mathrm{m}^{3}$ and ' $\mathrm{k}$ ' denotes efficiency factor.

By knowing the amounts of ' $c$ ', ' $w$ ' and the strength ' $S$ ' achieved for each slag dosage from the finally arrived experimental values, efficiency factor ' $k$ ' has been computed for each of the dosages.

Equation (1) has been shown to practically reduce to following two equations

$\mathrm{S}=\mathrm{A}[(\mathrm{C} / \mathrm{W})-0.5]$

$\mathrm{S}=\mathrm{A}[(\mathrm{C} / \mathrm{W})+0.5]$

These two equations represent two ranges of concrete strengths and it is due to the often observed fact that a change in slope occurs at about $\mathrm{w} / \mathrm{p}=0.25$, when $\mathrm{P} / \mathrm{W}$ (powder-water ratio) is plotted against strength. However, it is found that the equation (2) is useful for most of the present day concretes when an analysis was done on test results available and also the extensive data published by Larrard who also mentions this equation in his famous book, on 'Concrete Mix Proportioning - A scientific approach'. Therefore, equation (2) can be generally used for re-proportioning. The value of constant 'A' can be found out for the given concrete ingredients, by considering a concrete mix of any $\mathrm{w} / \mathrm{c}$ ratio.

For structural concrete, Equation (1) can be simplified as $\mathrm{S}=\mathrm{A}[(\mathrm{C} / \mathrm{W})-0.5]--$

A strength efficiency factor, $\mathrm{k}$, can then be computed using modified bolomey equation

$\mathrm{S}=\mathrm{A}[(\mathrm{C}+\mathrm{kP} / \mathrm{W})-0.5]$

Where $\mathrm{P}$ is the amount of powder replaced by weight of cement. Thus, $\mathrm{W} /(\mathrm{C}+\mathrm{kP})$ is the water/effective powderratio.

\subsection{Cementing Efficiency Factor, $K$}

This factor describes the mineral admixture's ability to act as cementing material recognizing that mineral admixture's contribution to concrete strength which comes mainly from its ability to react with free calcium hydroxide produced during cement hydration. The rate of this reaction, called as pozzolanic reaction (PR), when compared to cement hydration rate (CHR) determines the value of $k$. When $k=1$, both PR and CHR would be same and the water-binder ratios of concretes with and without MA could be almost same.

When $k<1$, PR would be slower than CHR and for equal strengths, the water-binder ratio of concrete with mineral admixture need to be less than that of concrete without mineral admixture and also, at same water-binder ratio, the strength of concrete with mineral admixture would be less than that of concrete without mineral admixture . In this case, the mineral admixture is less efficient than Portland cement in imparting strength to concrete. The GGBS has generally $k<1$ at early ages and $k$ would reach a value of unity at later ages.

When $\mathrm{k}>1$, PR would be faster than CHR and for equal strengths, the water-binder ratio of concrete with mineral admixture would to be more than that of concrete without mineral admixture .However, at similar water-binder ratios, the strength of concrete with mineral admixture would be more than that of concrete without mineral admixture. In this case, the mineral admixture is more efficient than Portland cement in imparting strength to concrete.

The contribution of MK and MS to any property of hardened concrete may be expressed in terms of efficiency factor, $\mathrm{k}$. Based on the average compressive strength of the control SCC mix (100\% OPC), 'A'value was calculated using Bolomey equation. Then Efficiency factors for $\mathrm{MK}, \mathrm{MS}, \mathrm{MK}+\mathrm{FA}$ and $\mathrm{MS}+\mathrm{FA}$ replaced SCC mixes were then determined using same bolomey equation. For this new material to be generally accepted by the building industry, a good durability must be proven also in quantitative terms. Therefore a big challenge for researchers within this field is to determine the strength efficiency of $\mathrm{MK}+\mathrm{FA}$ and $\mathrm{MS}+\mathrm{FA}$ in SCC.

\section{EXPERIMENTAL INVESTIGATIONS}

\subsection{Determination Of Quantities Of Materials For SCC Mixes}

Based on Nan Su mix design method, quantities required for 1 cu.m are evaluated for high strength grade (M80) of binary, ternary and quaternary blended Self Compacting Concrete (SCC) made with SCMs such as Fly Ash (FA), Microsilica (MS) and Metakaolin(MK). Final quantities, for all SCC mixes considered, are assumed after several trial mixes on quantities computed using Nan $\mathrm{Su}$ mix design method subjected to satisfaction of EFNARC flow properties. This phase identifies the optimum proportions of fly ash, micro silica and met kaolin in binary, ternary and 
quaternary blended SCC for enhanced performance of SCC at all ages.

The following are the quantities of materials calculated using Nan Su mix design method for high strength grade
(M80) based Self Compacting Concrete (SCC) and also presented the final quantities of materials after various trial mixes.

Table-1: Quantities per 1 cu.m for high strength (M80) grade SCC obtained using Nan Su method of Mix Design

\begin{tabular}{|c|c|c|c|c|c|c|c|c|}
\hline $\begin{array}{c}\text { Grade } \\
\text { of } \\
\text { SCC } \\
\text { Mix }\end{array}$ & Cement & $\begin{array}{c}\text { Pozzolana } \\
\text { (Fly ash) }\end{array}$ & $\begin{array}{c}\text { Fine } \\
\text { aggregate }\end{array}$ & $\begin{array}{c}\text { Coarse } \\
\text { aggregate }\end{array}$ & S.P. & $\begin{array}{c}\text { Water } \\
\text { Water/Powder } \\
\text { Ratio }\end{array}$ \\
\hline M80 & $\begin{array}{c}\text { Quantity } \\
\mathrm{kg} / \mathrm{m}^{3}\end{array}$ & 644 & 13 & 821 & 778 & $10.6 \mathrm{~L}$ & $165 \mathrm{~L}$ & 0.25 \\
\hline
\end{tabular}

The amount of total powder (i.e., OPC+FA) $(=450+410)$ for M80 grade blended SCC is $860 \mathrm{~kg} / \mathrm{m}^{3}$.Using Nan Su method, for M80 grade blended SCC ,computed total weight of pozzolanic material (100\% fly ash) is $13 \mathrm{~kg} / \mathrm{m}^{3}(2 \%$ of total powder) .For the above powder content shown in
Table-1, flow properties are not achieved as per EFNARC guidelines, so several trail mixes were carried out to satisfy the flow properties. The following SCC mix proportions are arrived at after several trail mixes conforming EFNARC specifications for the required fresh properties.

Table-2: Final Quantities per 1 cu.m for high strength (M80) grade SCC mix after trail mixes

\begin{tabular}{|c|c|c|c|c|c|c|c|c|}
\hline $\begin{array}{c}\text { Grade } \\
\text { of SCC } \\
\text { Mix }\end{array}$ & Cement & $\begin{array}{c}\text { Pozzolana } \\
\text { (Fly ash) }\end{array}$ & $\begin{array}{c}\text { Fine } \\
\text { aggregate }\end{array}$ & $\begin{array}{c}\text { Coarse } \\
\text { aggregate }\end{array}$ & S.P. & Water & $\begin{array}{c}\text { Water/Powder } \\
\text { Ratio }\end{array}$ \\
\hline M80 & $\begin{array}{c}\text { Quantity } \\
\mathrm{kg} / \mathrm{m}^{3}\end{array}$ & 450 & 410 & 821 & 778 & $10.6 \mathrm{~L}$ & $215 \mathrm{~L}$ & 0.25 \\
\hline
\end{tabular}

The following tables will illustrate the process of optimization of quantities of SCMs such as FA, MS and MK. For various binary, ternary and quaternary blended SCC mixes of high strength grade (M80), the tables demonstrate the strength achieved for various percentage replacements of pozzolanic materials considered in the study. The table-4 presents the final Optimal Quantities of various grades of SCC mixes. Table -5 presents Compressive strength properties for Optimum SCC mixes made with combination of FA, MS and MK as SCMs. Table-6 presents total powder content and water powder ratios for various grades of blended SCC mixes. Table-7 to Table-9 presents Bolomey's Coefficient (A) for Bolomey's equation and Cementing Efficiency Factors.

Table 3: Trial Mixes for Fresh Properties High Strength M80 Grade SCC to optimize quantities of SCMS

\begin{tabular}{|c|c|c|c|c|c|c|c|c|c|c|}
\hline \multirow[b]{2}{*}{$\begin{array}{l}\text { Mix } \\
\text { No. }\end{array}$} & \multirow[b]{2}{*}{ Mix Designation } & \multicolumn{4}{|c|}{$\begin{array}{l}\text { Replacement Percentage } \\
\text { (bwp)* }\end{array}$} & \multicolumn{2}{|c|}{$\begin{array}{l}\text { Slump Flow } \\
\text { kg per cu.m }\end{array}$} & \multicolumn{2}{|c|}{ V-Funnel } & \multirow{2}{*}{$\begin{array}{c}\text { L-box } \\
\begin{array}{c}\text { Blocking } \\
\text { ratio }\end{array}\end{array}$} \\
\hline & & OPC & FA & MS & MK & $\begin{array}{c}\text { Slump } \\
\text { Flow } \\
\text { Diameter } \\
\text { Mm }\end{array}$ & $\begin{array}{c}\mathrm{T}-50 \\
\mathrm{Sec}\end{array}$ & $\begin{array}{c}\mathrm{T}- \\
\text { OMin } \\
\text { sec }\end{array}$ & $\begin{array}{l}\text { T-5 } \\
\text { Min } \\
\text { sec }\end{array}$ & \\
\hline $\mathrm{C} 1$ & $\mathrm{C} 100$ & 100 & - & - & - & 707 & 3.22 & $6 . .3$ & 8.3 & 0.96 \\
\hline B1 & C52+FA48 & 52 & 48 & - & - & 780 & 2.7 & 5.2 & 6.8 & 0.84 \\
\hline $\mathrm{T} 1$ & C52+FA43+MS5 & 52 & 43 & 5 & - & 770 & 3.1 & 5.4 & 7.2 & 0.86 \\
\hline $\mathrm{T} 2$ & C52+FA38+MS10 & 52 & 38 & 10 & & 765 & 3.8 & 5.6 & 7.8 & 0.87 \\
\hline T3 & C52+FA33+MS15 & 52 & 33 & 15 & - & 740 & 4.2 & 6.1 & 12.1 & 0.96 \\
\hline $\mathrm{T} 4$ & C52+FA28+MS20 & 52 & 28 & 20 & - & 700 & 4.6 & 7.2 & 14.1 & 0.98 \\
\hline T5 & C52+FA43+MK5 & 52 & 43 & - & 5 & 770 & 2.9 & 5.1 & 6.9 & 0.84 \\
\hline T6 & C52+FA38+MK10 & 52 & 38 & - & 10 & 760 & 3.4 & 4.9 & 8.8 & 0.82 \\
\hline $\mathrm{T} 7$ & C52+FA33+MK15 & 52 & 33 & - & 15 & 710 & 3.8 & 5.3 & 10.8 & 0.94 \\
\hline T8 & C52+FA28+MK20 & 52 & 28 & - & 20 & 705 & 4.2 & 5.6 & 11.4 & 0.96 \\
\hline Q1 & C52+FA40+MS4+MK4 & 52 & 40 & 4 & 4 & 760 & 2.8 & 5.1 & 6.3 & 0.86 \\
\hline Q2 & C52+FA36+MS6+MK6 & 52 & 36 & 6 & 6 & 730 & 3.2 & 4.8 & 8.1 & 0.94 \\
\hline Q3 & C52+FA34+MS7+MK7 & 52 & 34 & 7 & 7 & 710 & 3.8 & 4.9 & 8.4 & 0.93 \\
\hline
\end{tabular}


Table-4: Trail mixes of various high strength grade(M80) blended SCC mixes to optimize quantities of SCMs

\begin{tabular}{|c|c|c|c|c|c|c|c|c|c|c|}
\hline \multirow[t]{2}{*}{ Mix No. } & \multirow[t]{2}{*}{ Mix Designation } & \multicolumn{4}{|c|}{$\begin{array}{c}\text { Replacement } \\
\text { Percentage }(\text { bwp) }\end{array}$} & \multicolumn{4}{|c|}{$\begin{array}{l}\text { Quantities } \\
\text { kg per cu.m }\end{array}$} & \multirow[t]{2}{*}{$\begin{array}{c}\text { Achieved } \\
\text { Strength(MPa) }\end{array}$} \\
\hline & & OPC & FA & MS & MK & OPC & FA & MS & MK & \\
\hline $\mathrm{C} 1$ & $\mathrm{C} 100$ & 100 & - & - & - & 860 & - & - & - & 84 \\
\hline B 1 & C52+FA48 & 52 & 48 & - & - & 450 & 410 & - & - & 59 \\
\hline T1 & C52+FA43+MS5 & 52 & 43 & 5 & - & 450 & 370 & 40 & - & 67 \\
\hline $\mathrm{T} 2$ & C52+FA38+MS10 & 52 & 38 & 10 & & 450 & 327 & 83 & - & 74 \\
\hline T3 & C52+FA33+MS15 & 52 & 33 & 15 & - & 450 & 284 & 126 & - & 86 \\
\hline $\mathrm{T} 4$ & C52+FA28+MS20 & 52 & 28 & 20 & - & 450 & 241 & 169 & - & 89 \\
\hline T5 & C52+FA43+MK5 & 52 & 43 & - & 5 & 450 & 370 & - & 40 & 65 \\
\hline T6 & C52+FA38+MK10 & 52 & 38 & - & 10 & 450 & 327 & - & 83 & 71 \\
\hline $\mathrm{T} 7$ & C52+FA33+MK15 & 52 & 33 & - & 15 & 450 & 284 & - & 126 & 84 \\
\hline T8 & C52+FA28+MK20 & 52 & 28 & - & 20 & 450 & 241 & - & 169 & 87.3 \\
\hline Q1 & C52+FA40+MS4+MK4 & 52 & 40 & 4 & 4 & 450 & 344 & 33 & 33 & 74 \\
\hline Q2 & C52+FA36+MS6+MK6 & 52 & 36 & 6 & 6 & 450 & 310 & 50 & 50 & 88 \\
\hline Q3 & C52+FA34+MS7+MK7 & 52 & 34 & 7 & 7 & 450 & 290 & 60 & 60 & 92.7 \\
\hline
\end{tabular}

Table-5: Final Optimal Quantities of various grades of SCC mixes

bwp ${ }^{*}$ - By weight of Total Powder content calculated from Nan Su mix design method

\begin{tabular}{|c|c|c|c|c|c|c|c|c|c|c|c|c|}
\hline \multirow[t]{2}{*}{ Grade of SCC Mix } & \multirow[t]{2}{*}{$\begin{array}{c}\text { Mix } \\
\text { No }\end{array}$} & \multirow[t]{2}{*}{$\begin{array}{c}\text { Mix Designation } \\
\text { (Values indicate percentage by } \\
\text { weight of ' } P \text { ' }\end{array}$} & \multicolumn{4}{|c|}{$\begin{array}{c}\text { Replacement } \\
\% \\
(\text { bwp) }\end{array}$} & \multicolumn{4}{|c|}{$\begin{array}{l}\text { Quantities } \\
\text { kg per cu.m }\end{array}$} & \multirow{2}{*}{$\begin{array}{c}\text { Total Powder } \\
\text { Content } \\
\text { 'P' kg }\end{array}$} & \multirow[t]{2}{*}{$\begin{array}{c}\text { Water } \\
\text { Powder Ratio } \\
\text { W/P }\end{array}$} \\
\hline & & & OPC & $\mathrm{FA}$ & MS & MK & $\mathrm{OPC}$ & $\mathrm{FA} \mid$ & $\mathrm{MSI}$ & $\mathrm{MK}$ & & \\
\hline \multirow{5}{*}{ M80 } & $\mathrm{C} 1$ & $\mathrm{C} 100$ & 100 & - & - & - & 860 & \begin{tabular}{|l|}
- \\
\end{tabular} & - & - & 860 & 0.25 \\
\hline & B1 & C52+FA48 & 52 & 48 & - & - & 450 & 410 & - & - & 860 & 0.25 \\
\hline & $\mathrm{T} 4$ & C52+FA28+MS20 & 52 & 28 & 20 & - & 450 & 2411 & 169 & - & 860 & 0.25 \\
\hline & T8 & C52+FA28+MK20 & 52 & 28 & - & 20 & 450 & 241 & - & 169 & 860 & 0.25 \\
\hline & Q3 & C52+FA34+MS7+MK7 & 52 & 34 & 7 & 7 & 450 & 290 & 60 & 60 & 860 & 0.25 \\
\hline
\end{tabular}

Table-6: Determination of Hardened Properties for Optimum SCC mixes made with combination of FA, MS and MK as SCMs

\begin{tabular}{|c|c|c|c|c|c|c|c|c|c|}
\hline \multirow{2}{*}{ S.No. } & \multirow{2}{*}{ Grade of SCC Mix } & \multirow{2}{*}{ Mix No } & \multirow{2}{*}{$\begin{array}{c}\text { Mix Designation } \\
\text { (Values indicate percentage } \\
\text { by weight of Total Powder) }\end{array}$} & \multicolumn{6}{|c|}{ Compressive Strength(MPa) } \\
\hline & & & & $\begin{array}{c}3 \\
\text { days }\end{array}$ & $\begin{array}{c}7 \\
\text { days }\end{array}$ & $\begin{array}{c}14 \\
\text { days }\end{array}$ & $\begin{array}{c}28 \\
\text { days }\end{array}$ & $\begin{array}{c}60 \\
\text { Days }\end{array}$ & $\begin{array}{c}90 \\
\text { days }\end{array}$ \\
\hline 1 & \multirow{13}{*}{ M80 } & $\mathrm{C} 1$ & C100 & 31.5 & 42 & 61.2 & 78.3 & 81.2 & 84 \\
\hline 2 & & B1 & C52+FA48 & 10.8 & 18.4 & 28.6 & 38.6 & 51.3 & 59 \\
\hline 3 & & $\mathrm{~T} 1$ & C52+FA43+MS5 & 15.3 & 21.4 & 31.4 & 47.2 & 63.2 & 67.1 \\
\hline 4 & & $\mathrm{~T} 2$ & C52+FA38+MS10 & 20.8 & 26.4 & 36.8 & 56 & 67.8 & 74.2 \\
\hline 5 & & T3 & C52+FA33+MS15 & 21.8 & 38 & 47 & 66.2 & 77.1 & 86.3 \\
\hline 6 & & $\mathrm{~T} 4$ & C52+FA28+MS20 & 31.5 & 58.2 & 69.2 & 85.1 & 87.2 & 89.1 \\
\hline 7 & & T5 & C52+FA43+MK5 & 17.2 & 31.4 & 37.1 & 52.1 & 61.2 & 65 \\
\hline 8 & & T6 & C52+FA38+MK10 & 25 & 33.2 & 42.1 & 59 & 66 & 71 \\
\hline 9 & & $\mathrm{~T} 7$ & C52+FA33+MK15 & 33.1 & 43.2 & 49.2 & 64 & 76.2 & 84.1 \\
\hline 10 & & T8 & C52+FA28+MK20 & 38.3 & 61.2 & 56.2 & 65.6 & 74.2 & 87.3 \\
\hline 11 & & Q1 & C52+FA40+MS4+MK4 & 16.4 & 28.2 & 37.2 & 43.2 & 68.6 & 74.4 \\
\hline 12 & & Q2 & C52+FA36+MS6+MK6 & 34.2 & 49.1 & 62.1 & 74.4 & 82.4 & 88 \\
\hline 13 & & Q3 & C52+FA34+MS7+MK7 & 41.4 & 62.1 & 68.1 & 85.1 & 89 & 92.7 \\
\hline
\end{tabular}

Table-7: Bolomey's Coefficients (A) for various grades of binary, ternary and quaternary blended SCC mixes

\begin{tabular}{|c|c|c|c|c|c|c|}
\hline \multirow{2}{*}{ Grade of SCC Mix } & \multicolumn{5}{|c|}{ Bolomey's Coefficients (A) } \\
\cline { 2 - 7 } & 3 Days & 7 days & 14 days & 28 days & 60 days & 90 days \\
\hline M80 & 9 & 12 & 17.48 & 22.37 & 23.2 & 24 \\
\hline
\end{tabular}


Table-8: Cementing Efficiency Factors at different ages

\begin{tabular}{|c|c|c|c|c|c|c|c|c|c|}
\hline \multirow{2}{*}{ SNo } & \multirow{2}{*}{ Grade of SCC Mix } & \multirow{2}{*}{ Mix No } & \multirow{2}{*}{$\begin{array}{c}\text { Mix Designation } \\
\text { (Values indicate percentage } \\
\text { by weight of Total Powder) }\end{array}$} & \multicolumn{6}{|c|}{ Efficiency Factors } \\
\hline & & & & \begin{tabular}{c|}
3 \\
days
\end{tabular} & $\begin{array}{c}7 \\
\text { days }\end{array}$ & $\begin{array}{c}14 \\
\text { days }\end{array}$ & $\begin{array}{c}28 \\
\text { days }\end{array}$ & $\begin{array}{c}60 \\
\text { days }\end{array}$ & $\begin{array}{c}90 \\
\text { days }\end{array}$ \\
\hline 1 & \multirow{4}{*}{ M80 } & $\mathrm{C} 1$ & C100 & \begin{tabular}{|l|}
- \\
\end{tabular} & - & - & - & - & - \\
\hline 2 & & $\mathrm{~T} 4$ & C52+FA28+MS20 & 1.01 & 1.71 & 1.24 & 1.16 & 1.13 & 1.11 \\
\hline 3 & & $\mathrm{~T} 8$ & $\mathrm{C} 52+\mathrm{FA} 28+\mathrm{MK} 20$ & 1.4 & 1.84 & 1.15 & 1.11 & 1.12 & 1.07 \\
\hline 4 & & Q3 & C52+FA28+MS7+MK7 & \begin{tabular}{|c|}
1.57 \\
\end{tabular} & 1.88 & 1.2 & 1.6 & 1.18 & 1.2 \\
\hline
\end{tabular}

\section{DISCUSSIONS}

* Table-1 presents the quantities per 1 cu.m for M80 grade SCC obtained using Nan Su method of Mix Design but for the powder quantities computed using this mix design method is not satisfying flow properties as per EFNARC guidelines, so several trail mixes were carried out to satisfy the flow properties. The final powder quantities for Standerd grade (M80) SCC mix are arrived at after several trail mixes conforming EFNARC specifications for the required fresh properties as shown in Table-2. From these final quantities, for various percentage replacement of cement by FA, MS, MK and their combinations are tried to optimize the quantities for binary, ternary and quaternary blended SCC mixes of grades considered. The percentage replacements, their corresponding desired strengths are tabulated in Table-3. In Table-4, final optimal quantities of various grades of SCC mixes along with their total powder content and water /powder ratios are mentioned. In Table-5, compressive strengths for various binary, ternary and quaternaryblended optimal SCC mixes are tabulated.

* For M80 grade SCC made with 100\%OPC, EFNARC flow specifications and target compressive strength at 90 days can be accomplished. Equivalent compressive strengths can be achieved at 90 days for FA based binary, ternary and quaternaryblended SCC systems. In ternary blended M80 grade SCC system, for $\mathrm{OPC}+\mathrm{FA}+\mathrm{MS}$ and $\mathrm{OPC}+\mathrm{FA}+\mathrm{MK}$ combinations , compressive strengths comparable to that of 90 days target strength of $100 \%$ OPC high stength grade SCC can be achieved. For all the above binary, ternary and quaternarycombinations of SCMs, EFNARC flow specifications are satisfied.

* Compressive strengths are achieved early in MetaKaolinbased ternary and quaternaryblended SCC of all grades than in microsilica based ternary and quaternaryblended SCC. Due to synergy effect, the interaction of two or more admixtures is so that their combined effect is greater than the sum of their individual effects. In the other words, for reflecting synergic effect, the efficiency factor of Metakaolin, microsilica and fly ash combinationshould be higher in quaternaryblended SCC than in ternaryblended SCC system. For calculating the efficiency of Metakaolin, microsilica and fly ash combination in ternaryand quaternaryblended SCC, an equation has been proposed by author based on the principle of Bolomey's equation for predicting the strength of concrete containing mineral admixtures. The efficiency factors evaluated can be used for proportioning of blended SCC.

* In ternary blended SCCcompressive strength of MS and MK based SCC mixes, $\mathrm{K}$ is in the range of 1.11 to 1.07 , which means that in a given SCC mix $1 \mathrm{KG}$ of MS or $1 \mathrm{KG}$ of $\mathrm{MK}$ based pozzolanic materials may replace 1.11. to $1.07 \mathrm{~kg}$ of cement without impairing the compressive strength .This may be valid, provided that the water content is kept constant. Bolomey's coefficients ' $A$ ' are calculated from the control mixes. Using computed ' $A$ ' value, calculate strength efficiency factors $\mathrm{k}$ at all ages for all percentage replacement levels of $\mathrm{MS}+\mathrm{FA}, \mathrm{MK}+\mathrm{FA}, \mathrm{MS}, \mathrm{MK}$ and FA combination in SCC.

* It is observed from efficiency factor is 1.11 for C52+FA28+MS20 and1.07 for C52+FA28+MK20 combinationsIn quaternary blended $\mathrm{SCC}$ it is observed from efficiency factor 1.19 for C52+FA34+MS7+MK7. It means that $1 \mathrm{~kg}$ of MK or $1 \mathrm{~kg}$ of MS based pozzolanic material may replaced by $1.19 \mathrm{~kg}$ of cement quarternary blended mix is found to be more efficient because of high usage of waste byproduct $\mathrm{FA}(34 \%)$ with equal dosage of MS and MK

\section{CONCLUSIONS}

[1]. Compressive strengths are achieved early in MetaKaolin based ternary and quaternary blended SCC.

[2]. Due to synergy effect, the interaction of two or more admixtures is so that their combined effect is greater than thesum of their individual effects.

[3]. For calculating the efficiency of MetaKaolin, Microsilica and fly ash combination in ternaryand quaternary blended SCC, an equation has been proposed by author based on the principle of Bolomey's equation for predicting the strength of concrete containing mineral admixtures.

[4]. In ternary blended SCCcompressive strength of MS and MK based SCC mixes, $\mathrm{K}$ is in the range of 1.11 to 1.07 , which means that in a given SCC mix $1 \mathrm{KG}$ of MS or $1 \mathrm{KG}$ of $\mathrm{MK}$ based pozzolanic materials may replace 1.11 . to $1.07 \mathrm{~kg}$ of cement without impairing the compressive strength .This may be valid, provided that the water content is kept constant. Bolomey's coefficients ' $\mathrm{A}$ ' are calculated from the control mixes. Using computed ' $\mathrm{A}$ ' value, calculate strength efficiency factors $\mathrm{k}$ at all ages for all percentage 
replacement levels of $\mathrm{MS}+\mathrm{FA}, \mathrm{MK}+\mathrm{FA}, \mathrm{MS}, \mathrm{MK}$ and FA combination in SCC.

[5]. It is observed from efficiency factor is 1.11 forC52+FA28+MS20 and 1.07 for C52+FA28+MK20 combinations.

[6]. In quaternary blended SCC it is observed from efficiency factor 1.19 for C52+FA34+MS7+MK7.It means that $1 \mathrm{~kg}$ of MK or $1 \mathrm{~kg}$ of MS based pozzolanic material may be replaced by $1.19 \mathrm{~kg}$ of cement.

[7]. Quaternary blended mix is found to be more efficient because of high usage of waste byproduct FA(34\%) with equal dosage of MS and MK

[8]. Due to substantial saving in quantity of cement, ternary and quaternary blended MK, FA based SCC is considered as Green High Performance Concrete, because cement was replacing to maximum level with improvement of the performance properties. Therefore ternary and quaternary blended SCC reduces environmental and helps in sustainable development

[9]. The findings of the present work endorses the recommendation that use of Microsilica and MetaKaolin in fly ash based SCC enhances both strength and replacement percentages of cement by mineral admixtures $s$ found to be cost effective in terms of less cement usage, increased use of fly ash and also plays a major role in early strength development of FA based SCC

[10]. In summary, the Microsilica and MetaKaolin based ternary and quaternary blended SCC gives better cohesiveness and solves problem of bleeding of ternary blended Microsilica based SCC and also adjusts the loss of workability which is a case of SCC blended with Micro Silica

[11]. MetaKaolin based ternary and quaternary blended SCC reduces the setting times and imparts early strength when compared to ternary and quaternary blend SCC with Micro Silica

[12]. It was observed that MetaKaolin based ternary and quaternary blended SCC requires less dosage of SP when compared to ternary and quaternary blended SCC with Micro Silica and which can be cost effective

\section{REFERENCES}

[1]. De Silva, P.S. and F.P. Glasser, 1990. Hydration of cements based on metakaolin: thermochemistry. Advances in Cement Research, 3: 167-177.

[2]. Ambroise, J., S. Maxmilien and J. Pera, 1994. Properties of MK blended cement. Advanced Cement Based Materials, 1: 161-168.

[3]. Wild, S., J.M. Khatib and A. Jones, 1996. Relative strength pozzolanic activity and cement hydration in superplasticised MK concrete. Cement and Concrete Research, 26: 1537-1544.

[4]. Wild, S., J.M. Khatib and M.J. Craythorne, 1997, Strength Development of Metakaolin Mortar. $5^{\text {th }}$ International Conference on Modern Building Materials. Structures and Techniques, Lithuania, Vilnius Gediminas Technical University, 1: 58-63.

[5]. Khatib, J.M., 2009. Low curing Temperature of Metakaolin Concrete. American Society of Civil
Engineers (ASCE) - Materials in Civil Engineering Journal, 21(8): 362-367.

[6]. Khatib, J.M., B.B. Sabir and S. Wild, 1996. Some properties of Metakaolin Paste and Mortar, International Conference Concrete in the Service of Mankind: Concrete for Environment Enhancement and Protection, (Eds. R.K. Dhir and T.D. Dyer), Dundee, pp: 637-643.

[7]. Sabir, B.B., S. Wild and J.M. Khatib, 1996. On the Workability and Strength Development of Metakaolin Concrete, International Conference - Concrete in the Service of Mankind: Concrete for Environment Enhancement and Protection, (Eds. R.K. Dhir and T.D. Dyer), pp: 651-662.

[8]. Sabir, B.B., J.M. Kinuthia, J.M. Khatib and M.A. Wustoff, 2001. Relative Strength and Workability of Metakaolin - Fly Ash Concrete, Seventh International Conference on Modern Building Materials, Structures and Techniques, Lithuania, Vilnius Gediminas Technical University, 1: 43-51.

[9]. Curcio, F., B.A. De Angelis and S. Pagliolico, 1998. Metakaolin as a pozzolanicmicro-filler for highperformance mortars, Cement and Concrete Research, 28(6): 803-809.

[10]. Khatib, J.M. and S. Wild, 1996, Pore size distribution of metakaolin paste, Cement and Concrete Research, 1545-1553.

[11]. Wild s,khatib JM,portlandite consumption in MetaKaolin cement pastes and mortars . cement concrete Res1997:27(I):137-46

[12]. Wild S.Khatib JM, Jones A. Relative strength ,pozzolanic activity and cement hyderation in superplasticied metakaolin concrete . cement concrete Res 1996;26(10):1537-44

[13]. Brooks JJ,Megat Johari , M.A, Mazloom M.Effect of admixtures on the setting times of high-strength concrete. Cement concrete compos 2000;22:293-301.

[14]. FIP, State of the art report : condensed silica fume in concrete, Thomas Telford,London, 1988.

[15]. 15,V.G Papadakis,s.Tsimas,supplementary cementing materials in concrete: part 1:Efficiency and design , cem ,concr. Res, 32(2002) 1525-1532.

[16]. A.M .Neville, properties of concrete , fourth ed., Addison Wesley Longman, Essex, UK.1996.

\section{BIOGRAPHIES}

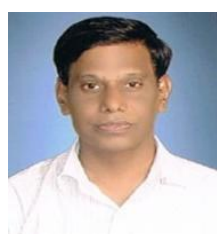

Mr. S Shrihari, is Research Scholar in Department of Civil Engineering, JNTUH. $\mathrm{He}$ is currently working as Professor and HOD in JBIET, Hyderabad. He has published 5 publications in Journals and Conferences. 